\title{
Farmer Empowerment in The Application Intercropping Technology of Chili Pepper (Capsicum Annum L.) and Cauliflower (Brassica Oleracea) in Bangodua District, Indramayu Regency
}

\author{
Kamilia Nur Asyaro'Aida, M. Tassim Billah, Yul Harry Bahar \\ Bogor Agricultural Development Polytechnic, Bogor and 16119, Indonesia \\ Bogor Agricultural Development Polytechnic, Bogor and 16119, Indonesia \\ Bogor Agricultural Development Polytechnic, Bogor and 16119, Indonesia \\ Email:kamilianurasyaroaida@gmail.com,tassim@yahoo.com andyul_bahar@yahoo.com
}

\section{ARTICLE INFO}

Date received : 01 September 2020

Revision date : 20 October 2020

Date received : 03 November 2020

\section{Keywords:}

Intercropping technology

Eempowermen

Productive

SWOT analysis

\begin{abstract}
This study aims to describe the empowerment of farmers in intercropping technology implementation, analyze the empowerment of farmers in the application of intercropping technology, and develop counseling strategies to increase the empowerment of farmers in the application of intercropping technology. Data were analyzed descriptively quantitatively, using multiple linear regression and determining extension strategies to increase farmer empowerment using SWOT analysis. The results showed that most farmers were of productive age (15-64 years old) with the dominant level of education in the low category (elementary / junior high) have monthly income ( $<R p 4,000,000)$ but have experience in farming with the experienced category (1116 years old). Factors that affect the empowerment of farmers in intercropping technology implementation are the level of education, farming experience, the intensity of empowerment, and information availability while the factors that have no effect such as age, income level, and social physical environment. The strategy used to improve empowerment uses SWOT analysis so that the strategies. The need to do is increase innovations adoption in terms of the benefits of intercropping technology that can stabilize the harvest price accumulation. Information literacy can utilize demographic bonuses in the form of many productive ages through online e-marketing. It aligns the development of information with the synergy of cooperation between competing factors related to maximizing the potential of farm products in the field.
\end{abstract}

\section{INTRODUCTION}

The agricultural sector is supporting the economy, positioned as a supplier of food and raw materials for low-priced industries, controlling price stabilization, and suppliers of cheap labor. The change in paradigm, including agricultural development, is demanded to be more democratic, transparent, and decentralized, and strive to realize the principles of good governance and community participation. The above approach is no longer relevant because what we want is that farmers and their families manage their farming businesses with full awareness rather than because they are forced to.

Over time, the welfare of farmers is getting worse in powerlessness and getting away from 
having independence in conducting their farming. Independence is meant as the ability manifestation of a person in utilizing his own potential to meet the needs of his life, which is characterized by the ability to determine the best freedom of choice. Chili farmers in Bangodua Subdistrict, Indramayu Regency, have long been in the business, but are yet far from the independent category. Like, the price of the harvest is determined by the collectors, farmers do not have market access to harvested products distribution, farmers are still trapped in the "mastery" of other parties, so they are not free in determining the best choice in carrying out farming activities.

Reflecting on the chili price development in the domestic market nationally, Bangodua District, Indramayu Regency fluctuates during the 20142016 period. The highest price peak occurred in December 2016. The increase in the price of red cayenne pepper was up to Rp. 90,000 / kg and large red and curly chili reached $\mathrm{Rp}$. 70,000 / kg. After that, the highest price of chili is always below $\mathrm{Rp}$ 60,000 / kg and in the second quarter of 2016 namely April, May, June 2016 national chili prices are relatively stable between $\mathrm{Rp} 30,000 / \mathrm{kg}$ to $\mathrm{Rp}$ 36,000 / kg. Required production planning and management policies for chili production patterns. (Ministry of Trade, 2016).

Inter-cropping technology is considered being an alternative food provider, which implies a mechanism for empowering farmers through counseling activities. Farmers participation is no longer just producing (backward linkage) but it acts as an industry, processing, and marketing (forward linkage) and gets a good price difference (profitseeking behavior) resulting from the empowerment process through extension activities joint with extension strategies using SWOT analysis and performance contributions from various parties such as farmers, extension agents, and related government agencies to realize farmers' selfsufficiency in Bangodua District, Indramayu Regency. The research aims 1) Describe the empowerment of farmers in Inter-cropping technology implementation; 2) Analyzing farmer empowerment, (3) Developing farmer empowerment strategies.

\section{METODE}

We conducted the study in March to June 2020 in three villages, namely: Malangsari Village, Wanasari Village, and Tegalgirang Village, Bangodua District, Indramayu Regency, West Java. The site choice was done purposively with the consideration that the area is an area of intercropping technology development for red chili and cabbage flower plants. The research method used by the survey method. We conducted a survey on several farmers with samples of red chili and cabbage flowers. The number of red chili farmers and cabbage flowers used as respondents was 80 respondents from three villages. Information in the form of primary data and secondary data.

\section{RESULTS AND DISCUSSION Internal factors}

Internal factors of the respondent farmers in this study comprised farmers doing farming in the cultivation field of red chilies and cabbage flowers, either in monoculture or inter-cropping. The following characteristics of the respondent farmers analyzed in this assessment are: (1) age at the time of the assessment, (2) formal education (3) farming experience, and (4) farmer income in conducting their farming.

Table 1.

Characteristics of Respondent Farmers

\begin{tabular}{lcc}
\hline \multicolumn{1}{c}{ Category } & N & (\%) \\
Age & & \\
Not productive yet: 0 -14 year & 2 & 2.5 \\
Earning:15-64 years old & 55 & 68.75 \\
Not productive ::> 64 years & 23 & 28.75 \\
old & & \\
\hline Level Education & & \\
Very low: No school (0) & 0 & 0 \\
Low: elementary / junior high & 78 & 97.5 \\
school / equivalent (1-9) & 2 & 2.5 \\
Medium: SMA / SMK (10-12) & 0 & 0 \\
High: Bachelor / diploma / & & \\
equivalent (13-16) & 6 & 7.5 \\
\hline Farming Experience & 30 & 37.5 \\
Less: <4 years & 40 & 50 \\
Enough: 5-10 years & 4 & 5 \\
Experience: $11-16$ years & & \\
Very Experienced:> 17 years & 36 & 45 \\
\hline Income Level & 11 & 13.8 \\
Low: <4M & 16 & 20 \\
Medium: $5 \mathrm{M}-8 \mathrm{M}$ & 17 & 21.3 \\
\hline Height: $9 \mathrm{M}-12 \mathrm{M}$ & & \\
Very high:> 13M & & \\
\hline Source: Primary data processed by & & \\
\hline
\end{tabular}

Source: Primary data processed by the author (2020)

\section{Farmer Age}

Based on the results of the study, most farmers aged 15 years to 64 years with a percentage of $68.75 \%$. This shows that the respondent farmers are in the productive age where the farmers are potential enough to do their farming supported by (Burhansyah \& PontianakTelp, 2019) which states that the productive age is the capital in carrying out farming activities and Widyastuti et al. (2016), which states that farmers of productive age are easier and faster to accept new technology or new program related to their farming activities. Whereas farmers with non-productive age according to (Andini, N.K., Nilakusmawati, D.P.E. dan Susilawati, 2013), farmers still work in old age because they do not have old age savings, so they must work to meet and guarantee the necessities of life. 


\section{Formal education}

Based on table 1, the characteristics of respondent farmers at the education level show that farmers with an elementary/junior high school / equivalent education level are 78 people or $97.5 \%$ of the total respondents' farmers. The low education owned by respondent farmers is in line with the results of research from (Anwarudin, 2017; Saputra et al.2018; Liani et al. 2018; Anggaraini et al. 2019; (Juhji et al., 2020) which states that generally farmers with formal elementary school education, so that the low level of education possessed by respondent farmers has the potential to experience a decline in their farm management, this is in line with the results of (Purwanti, 2007) research the low education respondents' condition in the future is worried, they cannot maintain their farmland properly.

\section{Farming Experience}

The experience of respondent farming in table 1 shows that the experience of respondent farmers during 11-16 years included in the category of experience 40 people or $50 \%$ caused by Longer farming experience is inherited from the parents of the results of the study in harmony with the results of the research by (Juhji et al., 2020) that farmers have worked at a young age and are inherited.

\section{Income Level}

The level of income received by farmers per month shows in table 1 shows that the level of income of farmers respondents less than Rp4,000,000.00 included in the low category of 36 people or $45 \%$ caused by the inability of respondents to access information, capital, markets, and agricultural production inputs. So that the income aspect affects the empowerment of farmers, where farmers' lower income can produce, managerial, and increase business scale is low.

\section{External Factors}

External factors in this study comprised the intensity of empowerment, social-physical environment and the information availability shows in table 2.

Table 2.

\section{Empowerment Factor Category Indicators}

\begin{tabular}{|c|c|c|c|c|}
\hline No & $\begin{array}{c}\text { Indicator } \\
\text { Value Criteria }\end{array}$ & $\begin{array}{c}\text { Value } \\
\text { Interval }\end{array}$ & $\mathbf{N}$ & $(\%)$ \\
\hline \multicolumn{5}{|c|}{ Empowerment Intensity (X2.1) } \\
\hline 1 & Low & $15-30$ & 35 & 43.75 \\
\hline 2 & Is & $>30-45$ & 41 & 51.25 \\
\hline 3 & High & $>45-60$ & 4 & 5 \\
\hline \multicolumn{5}{|c|}{ Average 33.45 (Medium) } \\
\hline \multicolumn{5}{|c|}{ Physical and Social Environment (X2.2) } \\
\hline 1 & Low & $15-30$ & 26 & 32.5 \\
\hline 2 & Is & $>30-45$ & 40 & 50 \\
\hline
\end{tabular}

\begin{tabular}{|c|c|c|c|c|}
\hline $\begin{array}{r}3 \\
\text { Ave }\end{array}$ & $\begin{array}{l}\text { High } \\
\text { ge } 35 .\end{array}$ & $>45-60$ & 14 & 17.5 \\
\hline \multicolumn{5}{|c|}{ Information Availability (X2.3) } \\
\hline 1 & Low & $15-30$ & 32 & 40 \\
\hline 2 & Is & $>30-45$ & 40 & 50 \\
\hline 3 & High & $>45-60$ & 8 & 10 \\
\hline
\end{tabular}

Average 33.80 (Medium)

Source: Primary data processed by the author (2020)

\section{Empowerment Intensity}

Based on the descriptive statistical analysis in table 2, it is known that the indicator of empowerment intensity is included in the moderate category at $51.25 \%$. Under the data analysis, it can be concluded that the indicator of empowerment intensity is in the medium category, because of counseling and mentoring methods that have been effective and targeted, but the lack of the nature of meetings attended by farmers on the grounds of busy running their farms.

\section{Physical and Social Environment}

Based on table 2 indicators of the physical and social environment in the moderate category is $50 \%$. That matter due to not all elements of the community empowered in inter-cropping planting patterns, government policy support was seen from the government helps in quality seeds procurement, procurement of fertilizers and medicines. With Presidential Regulation No. 54 of 2018 concerning procurement of quality service, goods can synergize between the government and related institutions that have been given the authority of management and distribution to be more synergized between the components involved in it.

\section{Information Availability}

Agricultural information availability shows in table 2 is one factor that influences the empowerment of farmers in applying cropping patterns intercropping. Data acquisition $50 \%$ of the respondent farmers are in the medium category. Most farmers in the medium category are caused by the uneven distribution of information among red chilies and flower cabbage farmers besides the increasing value of the benefits provided to farmers will affect the high participation of farmers in the study results in line with (Mulyaningsih, Hubeis, Sadono, \& Susanto, 2018) that the information availability contained in indicators of benefits, variety of information, and quality of information can increase farmer participation.

Support the opinions of that part of the information comes from farmers who play an active role in finding information, so that independence is needed to get information. Information related to the sector of cultivation of red chili and cabbage flowers in the field must be harmonized with the encouragement in the form of motivation to farmers to be more active in developing the source of information obtained implied by concrete action in the form of applying cropping patterns inter-cropping 
independently and based on good and correct cultivation guidelines.

\section{Level of Empowerment}

The level of empowerment in this research focuses on indicators of the ability to access information, the ability to access markets, and the ability to make decisions. Shows in the following table.

Table 3

Indicators of Empowerment Factors

\begin{tabular}{|c|c|c|c|c|}
\hline No & $\begin{array}{c}\text { Indicator } \\
\text { Value } \\
\text { Criteria } \\
\end{array}$ & $\begin{array}{c}\text { Value } \\
\text { Interval }\end{array}$ & $\mathbf{N}$ & $(\%)$ \\
\hline \multicolumn{5}{|c|}{ Ability to Access Information (Y1.1) } \\
\hline 1 & Low & 9-18 & 14 & 17.5 \\
\hline 2 & Is & $>18-27$ & 59 & 73,75 \\
\hline 3 & High & $>27-36$ & 7 & 8.75 \\
\hline \multicolumn{5}{|c|}{ Average 21.61 (moderate) } \\
\hline \multicolumn{5}{|c|}{ Market Access Ability (Y1.2) } \\
\hline 1 & Low & $9-18$ & 22 & 27.5 \\
\hline 2 & Is & $>18-27$ & 54 & 67.5 \\
\hline 3 & High & $>27-36$ & 4 & 5 \\
\hline \multicolumn{5}{|c|}{ Average 20.67 (moderate) } \\
\hline \multicolumn{5}{|c|}{ Decision Making Ability (Y1.3) } \\
\hline 1 & Low & $9-18$ & 16 & 20 \\
\hline 2 & Is & $>18-27$ & 57 & 71.25 \\
\hline 3 & High & $>27-36$ & 7 & 8.75 \\
\hline
\end{tabular}

Source: Primary data processed by the author (2020)

\section{Ability to Access Information}

Increased access to farmers' information shows in table 3, which also increases the ability of farmers to manage their agribusiness. It is expected through inter-cropping technology implementation in the red chili and cabbage flower, but seen from the results of a descriptive analysis of indicators, the ability to access information is in the medium category with an average acquisition of 21.61. It is proven from the numbeCr of 80 respondent farmers, 59 respondents farmers are in the medium category $73.75 \%$. Based on the results of the analysis and the real conditions in the field, it was found that the cause of farmers being in the medium category was the respondent farmers limitation in accessing information because not all farmers could access existing information, the lack of internet access is consistent with the results of research from Wijaya et al. (2019) facilities for internet access are still considered lacking. Internet access availability is important to help instructor performance to provide information to farmers. This gap affects the inefficient implementation of farming activities in the field.

\section{Ability to Access Markets}

The characteristics of the respondent farmers in the ability to access the market can be seen in table 3 based on the results of the descriptive analysis and the results of the field study that the ability to access the respondent farmers' market is in the medium category as evidenced by the 80 respondents of the farmers 54 farmers respondents are in the medium category $67.5 \%$. The reason for the ability to access the market is in the medium category is that some farmers pay less attention to the quality of the products they produce and the limited information on selling prices at the farmer level, middlemen, and marketing institutions. A reciprocal relationship between marketers and producers, namely farmers, farmer groups plays a role in driving agricultural development disseminating information to support the economic growth of the members of the farm group. This opinion is in line with the results of research by (Mulyaningtiyas \& Junaidi, 2020) that farmer groups in the implementation of activities directed at the growth and empowerment of group performance.

\section{Decision Making Ability}

Conditions in the field require farmers to be responsive to technological information, along with technology development some farmers are reluctant to adopt the technology accompanied by several reasons such as the difficulty of adopting technology and the lack of facilities and infrastructure. This is evidenced from

The results of the study in which of 80 respondent farmers, 16 farmers respondents were in the low category of $20 \%, 57$ respondents were in the medium category of $71.25 \%$, and 7 respondents were farmers in the high category of $8,75 \%$.

\section{Farmer Empowerment Process}

Empowerment as an endeavor to provide opportunities and abilities to the community to be able and brave to choose the best alternative for life improvement. The ability of farmers is influenced by the extent of their capabilities, the following capabilities owned by farmers in the District of Bangodua are illustrated in the picture. 


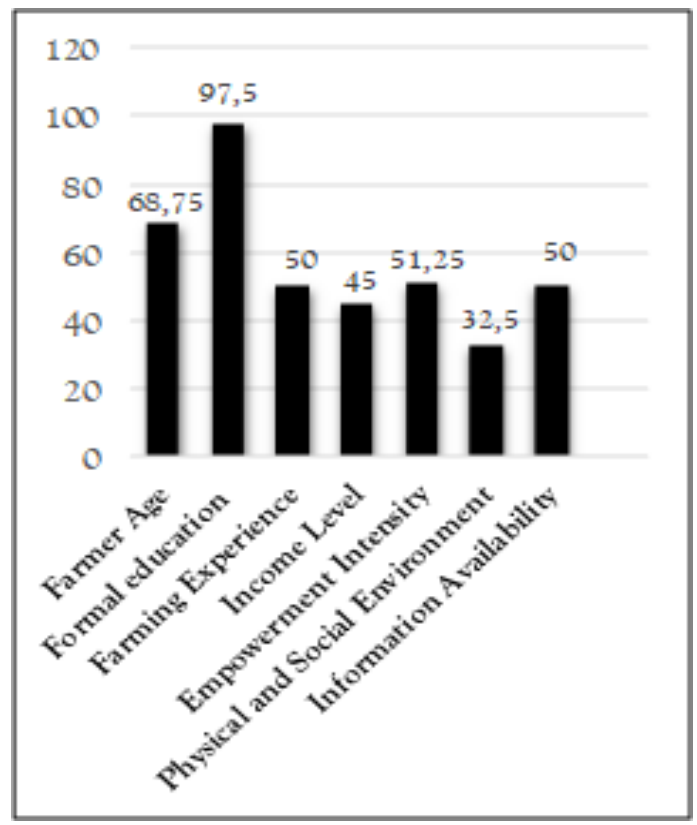

Picture 1. Capability of Respondent Farmers

Farmers' empowerment in implementing intercropping technology cannot be said to be empowered, it needs to be empowered through nonformal education, namely counseling activities. Based on the results of research on the process of empowerment of farmers in the inter-cropping technology implementation are in the medium category factors that cause the level of empowerment are in the medium category, namely farmers internal factors such as low education levels, monthly farming income $<4$ million and external factors such as the intensity of empowerment, social-physical environment, and information availability by $44.6 \%$. The results of the study are in line with (Everett $M$ Rogers \& Shoemaker, 1981) and (Sapar, 2016) that in the process of community empowerment are inseparable from the presence of internal and external factors.

The results of the analysis based on the research questionnaire and compiled with field study studies can be stated as follows that the high level of farming experience cannot indicate empowered farmers without being matched by changes in farmer's behavior in the perspective of cognitive, affective, and psychomotor improvement.

\section{Factors that Influence the Level of Empowerment}

The indicators studied comprise internal and external factors but which have an influence on the level of empowerment of farmers in implementing inter-cropping technology on red chili plants with cabbage flowers, namely: 1) formal education; 2) farming experience; 3) empowerment intensity; and 4) information availability which can be seen in the following table.

Table 4.
Influential Factors

\begin{tabular}{|c|c|c|c|}
\hline Description & Score & Sig. & Ket. \\
\hline$R^{2}$ & 0.270 & & \\
\hline A constant & 31,588 & .007 & \\
\hline X1.1 Age & 2,215 & 347 & * \\
\hline X1.2 Formal Education & 7,036 & .030 & ** \\
\hline X1.3 Farming Experience & 6,871 & .006 & ** \\
\hline X1.4 Income Level & $-1,423$ & .238 & * \\
\hline $\begin{array}{l}\text { X2.1 Empowerment } \\
\text { Intensity }\end{array}$ & 3,444 & .001 & ** \\
\hline $\begin{array}{l}\text { X2.2 Physical and Social } \\
\text { Environment }\end{array}$ & $-0,565$ & .071 & * \\
\hline $\begin{array}{l}\text { X2.3 Availability of } \\
\text { Information }\end{array}$ & $-2,656$ & .004 & ** \\
\hline F count & 3,806 & & \\
\hline
\end{tabular}

The multiple linear regression equation model used in this study is as follows:

$$
\begin{aligned}
& Y=31,588+2,215 \times 1.1+(-1,423) \times 1.4+(- \\
& 0.565) X 2.2
\end{aligned}
$$

The table shows a $F$ count of 3.806 with a significance level of 0.05 that the probability $<a$ tolerable level of significance $(0.00<0.05)$ then there is a simultaneous independent variable effect that is formal education, farming experience, intensity of empowerment, and information availability on the level of empowerment. It is known that there is an influence of formal education, farming experience, the intensity of empowerment, and information availability on the level of empowerment with a coefficient of determination (R2 Square) of 0.270 . This value means that the variables of formal education, farming experience, intensity of empowerment, and availability of information affect the level of empowerment by $27 \%$ lower than $73 \%$ which can be explained by other variables. High or low value of the coefficient of determination does not decide the results of the analysis precisely and accurately. This was in line with the results of the study Ghozali (2011) states that the purpose of regression analysis is to find the estimated value of the regression coefficient and to draw statistical inference so that the high or low value of $R 2$ is not problematic. If in the analysis process getting a high $R 2$ is good, a low $R 2$ value does not mean the regression model is not good.

\section{Effect of Education Level on Level of Empowerment}

Based on the results of the partial analysis, we can conclude it that formal education has a positive effect on the level of empowerment of farmers. This is evidenced by the partial test obtained by the regression coefficient for positive formal education indicators (7.036) so any increase in formal education will affect the level of empowerment of farmers in applying inter-cropping technology on red chili plants with cabbage flowers 
of 7.036 units. As for the t test of 2.210 is greater than the value of t table 1.993 and the significance of 0.30 is smaller than 0.05 , it can be concluded that the formal education indicators significantly influence the level of empowerment.

The results of this study are in line according to (E M Rogers, 2003) that the level of education can affect farmers' responses to the existence of technological innovation. This opinion is supported by (Yunita, 2012) that formal education can provide or increase the ability of farmers to decide and overcome low level of education of farmers. In this study, taken as a benchmark, is the formal education of farmer respondents to measure the level of knowledge that affects the empowerment of farmers.

\section{The Effect of Farming Experience on the Level of Empowerment}

Based on the results of analysts partially it can be concluded that the experience of farming has a positive effect on the level of empowerment. This is evidenced by the partial test obtained by the regression coefficient for positive value farming experience indicators $(6,871)$ which means that any increase in farming experience will affect an increase in empowerment of 6,871 units. As for the $t$ test, the $t$ value of 2.857 is greater than the $t$ table value of 1.993 and the significance of 0.006 is less than 0.05 , so it can be concluded that the indicator of farming experience has a positive effect on the level of empowerment of farmers.

The results of this study are in line with (Sarwono, 2002); (Putriani, Tenriawan, \& Amrullah, 2018). The level of experience of farming is one indicator that influences the successful application of inter-cropping technology on red chili plants and cabbage flowers by farmers. Farmers who are experienced and supported by complete production facilities will be better able to increase production, productivity, and income compared to farmers who have just started farming. Farming experience can affect the production of red chili with cabbage flowers. This is because the higher experience in running a farm has an impact, the better one's knowledge in conducting farming.

\section{The Effect of Empowerment Intensity on the Level of Empowerment}

Based on the results of the partial analysis we can conclude it that the intensity of empowerment has a positive effect on the level of empowerment. This is evidenced by the partial test of the regression coefficient obtained for the indicator of empowerment intensity positive value $(3,444)$ which means that every increase in the intensity of empowerment will affect an increase in the level of empowerment of 3,444 units. As for the test, the $t$ value of 3.377 is greater than the table value of 1.993 and the significance of 0.001 is less than 0.05 , it can be concluded that the empowerment indicator has a positive and significant effect on the level of empowerment.

These results are in line with opinion (Sarwoprasodjo, Hubeis, \& Sugihen, 2017); Alawiyah et al 2018) which states that the level of group empowerment is directly and positively influenced by implementing participatory development communication and encourages farmers' participation in the effort included that extension agents invite farmers together to find the information needed, help get seeds, fertilizers, vegetable pesticides or chemical pesticides according to the needs of farmers, help to get agricultural tools according to the needs of farmers, help farmers to get capital assistance under farmers' needs, and help farmers in finding market systems that benefit farmers.

\section{Effect of Information Availability on Level of Empowerment}

Based on the results of the partial analysis it can be concluded that information availability has a negative effect on the level of empowerment. This is evidenced by the partial test of the regression coefficient obtained for the indicator of the negative information availability (2.656) which means that any increase in information availability will affect the decrease in the level of empowerment by 2.656 units. For the t test, the calculated value of $t-2.992$ is smaller than the t-table value of 1.993 and the significance of 0.004 is less than 0.05 . It can be concluded that the indicator of information availability has a negative and significant effect on the level of empowerment.

The results of the study are in line with (Mulyaningsih et al., 2018) the better the quality of information received by both male and female farmers, the more participating in their farming so that in this study as a whole it is found that the availability of information in terms of relevance is complete, timely, and represented generally plays a role in stimulating farmers to more empowered. In general, farmers need information if there are new supporting technologies that are useful during the process of growing vegetables in line with the opinion that intercropping technology is an alternative technology that can be used in increasing production, productivity, and income, things like this are needed by farmers. This role of extension workers is very active role in providing information obtained to be disseminated to farmers.

\section{Intercropping Technology Improvement Strategy} Implementation of production-oriented extension activities turned out not necessarily in the same direction with increased income and welfare of farmers, not at the same time empowering farmers The right strategy is needed to increase the empowerment of farmers in inter-cropping technology implementation on red chilies with cabbage flowers, one of them is by using SWOT 
analysis based on logic that can maximize strengths and opportunities but at the same time minimizing weaknesses and threats of analyzing internal and external factors from respondent farmers to produce strategies that can be used in solving problems that are reformulated by determining appropriate strategies based from the results of internal external matrix (EI) to see the right quadrant position to produce a strategy to increase the empowerment of respondent farmers in implementing inter-cropping cropping patterns.

\section{Identification of Internal and External Factors}

Rauch (2007) that before describing it is necessary to analyze the situation, both internal (strengths and weaknesses) and external (opportunities and threats) The following is a description of the results of the identification of internal and external factors of respondent farmers.

Table 5.

IFAS and EFAS matric

\begin{tabular}{|c|c|c|c|}
\hline Internal factors & Weight & Rating & $\begin{array}{l}\text { Score } \\
(\mathrm{BxR})\end{array}$ \\
\hline \multicolumn{4}{|l|}{ Strength (strength) } \\
\hline $\begin{array}{l}\text { Work experience } \\
\text { of farmer HR in } \\
\text { the high category }\end{array}$ & 0.40 & 2.40 & 0.96 \\
\hline $\begin{array}{l}\text { Most farmers are } \\
\text { of productive age }\end{array}$ & 0.30 & 2.46 & .74 \\
\hline $\begin{array}{l}\text { Farmer's HR } \\
\text { skills are high }\end{array}$ & 0.30 & 2.40 & .72 \\
\hline Total Score & & & 2.42 \\
\hline \multicolumn{4}{|l|}{ Weakness } \\
\hline $\begin{array}{l}\text { The level of HR } \\
\text { education is } \\
\text { relatively low }\end{array}$ & 0.30 & 1.10 & 0.33 \\
\hline $\begin{array}{l}\text { Farmers' } \\
\text { knowledge about } \\
\text { intercropping } \\
\text { technology is } \\
\text { limited }\end{array}$ & 0.40 & 1.10 & 0.44 \\
\hline $\begin{array}{l}\text { The difficulty of } \\
\text { the process of } \\
\text { adoption of } \\
\text { intercropping } \\
\text { cultivation }\end{array}$ & 0.30 & 1.10 & 0.33 \\
\hline Total Score & & & 1.11 \\
\hline External Factors & Weight & Rating & $\begin{array}{l}\text { Score } \\
(B \times R)\end{array}$ \\
\hline \multicolumn{4}{|c|}{ Opportunity (Opportunities) } \\
\hline $\begin{array}{l}\text { Positive } \\
\text { perception of } \\
\text { farmers about } \\
\text { extension } \\
\text { activities }\end{array}$ & 0.30 & 2.23 & .67 \\
\hline $\begin{array}{l}\text { The existence of } \\
\text { extension } \\
\text { institutions that } \\
\text { play a role in } \\
\text { socializing }\end{array}$ & 0.40 & 2.23 & .89 \\
\hline
\end{tabular}

\begin{tabular}{|c|c|c|c|}
\hline External Factors & Weight & Rating & $\begin{array}{l}\text { Score } \\
\text { (BxR) }\end{array}$ \\
\hline \multicolumn{4}{|c|}{ Opportunity (Opportunities) } \\
\hline $\begin{array}{l}\text { Agricultural technology } \\
\text { information continues to } \\
\text { develop }\end{array}$ & 0.30 & 2.25 & .67 \\
\hline Total Score & & & 2.23 \\
\hline \multicolumn{4}{|l|}{ Threats } \\
\hline $\begin{array}{l}\text { The selling price of } \\
\text { products on the market } \\
\text { tends to fluctuate, } \\
\text { especially during the } \\
\text { main harvest }\end{array}$ & 0.40 & 2.35 & .94 \\
\hline $\begin{array}{l}\text { The lack of information } \\
\text { about marketing }\end{array}$ & 0.30 & 2.25 & .67 \\
\hline $\begin{array}{l}\text { Delay in the distribution } \\
\text { of beni. }\end{array}$ & 0.30 & 2.30 & 0.69 \\
\hline Total Score & & & 2.30 \\
\hline
\end{tabular}

Source: Primary data processed by the author (2020)

In table 5 shows the internal factors of the IFAS matrix and EFAS total strength score (strength) 2.42 (the total score resulting from the multiplication of weights with the rating to produce a total score). While the total score of weakness (weakness) 1.11 (the number of scores resulting from the multiplication of weights and ratings to produce a total score). and external factors the total opportunity score (opportunities) 2.23 is smaller than the total score of threats (threats) which is 2.30(the resulting total score comes from the multiplication of weights by rating to produce a total score). Difference in a total score of 0.7 makes the external factors of threats

(threats) greater than the total score of opportunities, (opportunities).

\section{Internal and External Matrices (IE)}

Determination of the quadrant position on the results of the sum of the IFAS and EFAS matrices, two ordinate points are obtained from the matrix of strengths and weaknesses, namely the first ordinate point: difference (strengths - weaknesses) = 1.31 and the matrix of opportunities and threats positions, namely second ordinate point: difference (chance threat) $=-0.07$ the total score derived from internal factors (strengths and weaknesses) and external factors (opportunities and threats) greater strength results in the $X$-axis while the threats faced are greater than the opportunity to produce the $\mathrm{Y}$-axis accumulation of the difference calculation from the IFAS matrix (1.31) and EFAS (-0.07). Resulting quadrant position is in quadrant II, namely ST diversification strategy using the power to reduce the risk of threats (strength-treats). or ST strategy according to (Swastika \& Indraningsih, 2020) is use force and minimize threats. 


\begin{tabular}{|c|c|}
\hline & Strength \\
\hline & $\begin{array}{ll}\text { 1. } & \text { Adequate farmer HR } \\
\text { work experience } \\
\text { 2. } \\
\text { Most farmers are of } \\
\text { productive age } \\
\text { 3. Agricultural } \\
\text { technology } \\
\text { information } \\
\text { continues to develop }\end{array}$ \\
\hline Threats & ST Strategy \\
\hline $\begin{array}{l}\text { 1. The selling price of } \\
\text { products on the } \\
\text { market tends to } \\
\text { fluctuate, especially } \\
\text { during the main } \\
\text { harvest } \\
\text { 2. The lack of } \\
\text { information about } \\
\text { offline and online } \\
\text { marketing } \\
\text { 3. Delay in the } \\
\text { delivery of aid } \\
\text { seeds, thereby } \\
\text { slowing planting }\end{array}$ & $\begin{array}{l}\text { 1. It is necessary to } \\
\text { increase the } \\
\text { adoption of } \\
\text { innovation in terms } \\
\text { of the benefits of } \\
\text { intercropping } \\
\text { technology that can } \\
\text { stabilize the } \\
\text { accumulation of } \\
\text { harvest prices so } \\
\text { that when the main } \\
\text { commodity is } \\
\text { harvested farmers } \\
\text { have a reserve fund } \\
\text { (safety money). } \\
\text { A demographic } \\
\text { bonus in the form of } \\
\text { many productive } \\
\text { ages can be } \\
\text { exploited by } \\
\text { information literacy } \\
\text { through online e- } \\
\text { marketing. } \\
\text { The development of } \\
\text { information is } \\
\text { harmonized with the } \\
\text { synergy of } \\
\text { cooperation between } \\
\text { interrelated factors in } \\
\text { order to maximize } \\
\text { the potential of farm } \\
\text { products in the field. }\end{array}$ \\
\hline
\end{tabular}

\section{ST Strategy (threat-threats)}

ST Strategy (strength-threats) that is using the power possessed by farmers to avoid threats in applying inter-cropping technology on red chili plants with cabbage flowers in Bangodua Subdistrict, Indramyu Regency, where the strategy that must be carried out is to increase the adoption of innovations. In terms of inter-cropping benefits that can stabilize harvest prices accumulation so that when the main commodity is harvested farmers have a reserve fund (soft money). Information literacy can utilize demographic bonuses in the form of many productive ages in e-marketing and offline and information development harmonized with synergy cooperation between factors interrelated to maximize the potential results of farming in the field.

\section{CONCLUSION}

Empowering farmers in applying intercropping technology to red chili and cabbage flowers in Bangodua District is in the medium category. Thus the level of empowerment of farmers with the inter-cropping technology impletion on red chilli plants and cabbage flowers in the District of Bangodua is influenced by several factors, namely: 1) internal factors including formal education and farming experience and 2) external factors, the intensity of empowerment and availability of information. And counseling strategies in increasing the empowerment of farmers in the District of Bangodua is to implement a diversification strategy.

\section{REFERENCES}

Alawiyah T, Sumantri A T, Gunawan G. 2018. Tingkat Partisipasi Petani dalam Program Perluasan Areal Tanaman (PAT) Kedelai (Glycine Max) (Studi Kasus Kelompok Tani di Desa Sudimanik Kecamatan Cibaliung Kabupaten Pandeglang). Jurnal Agribisnis Terpadu 11(2):168-180.

Alim, M. N. Trisni Hapsari dan Lilik Purwanti. 2007. Jurnal.

Andini, N.K., Nilakusmawati, D.P.E. dan Susilawati, M. 2013. Faktor-faktor yang memengaruhi penduduk lanjut usia masih bekerja. Piramida Jurnal Kependudukan dan Pengembangan Sumber Daya Manusia. $9(1): 44-49$.

Anwarudin O. 2017. Faktor Penentu Partisipasi Petani pada Program Upaya Khusus (UPSUS) Padi di Kabupaten Manokwari, Papua Barat. Jurnal Penyuluhan Pertanian. 12(1): 67-79.

Burhansyah, Rusli. 2014. Faktor-Faktor Yang Mempengaruhi Adopsi Inovasi Pertanian Pada Gapoktan Puap Dan Non Puap Di Kalimantan Barat (Studi Kasus: Kabupaten Pontianak Dan Landak). Jurnal IImu Pertanian Vol 23 No 1

D. Mulyaningtiyas, R., \& Junaidi, M. (2020). Community Empowerment of women's farmer groups: Utilizing the yard around the house. Prosiding Seminar, , 40-44. doi:10.32503/prosidingseminar.v0i0.26

Damanik, I. P., \& Tahitu, M. E. (2020). The Communication Behaviour of Farmers and Strategies to Strengthen the Capacity of Information Access in the Era of Industrial 
Revolution 4.0 in Ambon City. Jurnal Penyuluhan, 16(1), 92-104. https://doi.org/10.25015/16202026365

Diemer, N., Staudacher, P., Atuhaire, A., Fuhrimann, S., \& Inauen, J. (2020). Smallholder farmers' information behavior differs for organic versus conventional pest management strategies: A qualitative study in Uganda. Journal of Cleaner Production, 257, 120465.

Ermawati, Emmy dan Barlian, Noer Aisyah. 2018. "Pengaruh Kompensasi Langsung, Kompensasi Tidak Langsung, dan Kompensasi Non Finansial Terhadap Motivasi dan Kinerja Karyawan Klinik Swasta di Kabupaten Lumajang." Progress Conference. Vol. 1, No. 1, E-ISSN :2622304X, PISSN : 2622-3031. Agustus 2018.

Jaya, Muhammad \& Sarwoprasodjo, Sarwititi \& Hubeis, Musa \& Sugihen, Basita. (2017). Tingkat Keberdayaan Kelompok Tani pada Pengelolaan Usahatani Padi di Daerah Istimewa Yogyakarta, Jawa Tengah. Jurnal Penyuluhan. 13. 166. 10.25015/penyuluhan.v13i2.15903.

Liani F, Sulistyowati D, Anwarudin O. (2018). Perspektif gender dalam partisipasi petani pada Kawasan Rumah Pangan Lestari (KRPL) tanaman sayuran di Kecamatan Kersamanah Kabupaten Garut Provinsi Jawa Barat. Jurnal Penyuluhan Pertanian, 13(1), 21-32.

Mulyaningsih, A., Hubeis, A. V. S., Sadono, D., \& Susanto, D. (2018). Partisipasi petani pada usahatani padi, jagung, dan kedelai perspektif gender. Jurnal Penyuluhan, 14(1), 145-158.

Nadeak, B., Arifudin, O., Mustafa, M., Choiriyati, W., Hanika, I. M., Tanjung, R., \& Adiarsi, G. R. (2020). Manajemen Humas Pada Lembaga Pendidikan.

Purwanti, R. (2007). Pendapatan Petani Dataran Tinggi Sub DAS Malino. Jurnal Penelitian Sosial dan Ekonomi Kehutanan, 4(3), 257269.

Putriani R, Tenriawaru A N, Amrullah A. 2018. Pengaruh Faktor-Faktor Partisipasi Terhadap Tingkat Partisipasi Petani Anggota P3A dalam Kegiatan Pengelolaan Saluran Irigasi. Jurnal Sosial Ekonomi Pertanian 14(3): 263-274.

Rauch P. 2007. SWOT analysis and SWOT strategy formulation for forest owner cooperation in Austria. Eur J For Res.

126:413-420

RISTA. IV (3) : 476-485

Rogers, E.M. 2003. Diffusion of Innovations. Fifth Edition. The Free Press. New York.

Rogers, E.M. dan F.F. Schoemaker. 1981. Communication of Innovations: A Cross Cultural Approach. New York: The Free Press. A Division of Mc Milland Co.

Salkind, N.J. 1985. Teories Of Human Development. New York: John Willey and Sons.

Saputra C, Anwarudin O, Sulistyowati D. (2018). Persepsi dan adopsi pengendalian hama terpadu lalat buah pada tanaman mangga di Kecamatan Greged Kabupaten Cirebon Provinsi Jawa Barat. Jurnal Penyuluhan Pertanian, 46-60.

Sarwono, S. W. (2002). Psikologi Sosial: Individu dan Teori-teori Psikologi Sosial. Jakarta: PT. Balai Pustaka

Siddiq, D. M., \& Faqih, A. (2020, April). The Empowerment Strategy of Gapoktan Toward an Agribusiness Microfinance Institution in Rural Areas. In International Conference on Agriculture, Social Sciences, Education, Technology and Health (ICASSETH 2019) (pp. 193-197). Atlantis Press.

Sudiro, L. E. Models to Increase the Farmers' Participation on the Implementation of Lowland Rice Balanced Fertilization in Cikoneng Subdistrict Ciamis.

Swastika, D. K. S., \& Indraningsih, K. S. (2020). Strategy Formulation of Farmers Capacity Building through Technological Innovation in Disadvantaged Regions of Indonesia. Jurnal Agro Ekonomi, 38(1), 15-27.

Widiyastuti, E., Widiyanti, Sutarto. (2016). Persepsi Petani Terhadap Pengembangan System Of Rice Intensification (SRI) Di Kecamatan Moga Kabupaten Pemalang. Jurnal AG

Yanuarti, Astri Ridha dan Mudya Dewi Afsari. 2016. Profil Komoditas Barang Kebutuhan Pokok dan Barang Penting Komoditas Cabai. Jakarta: Kementerian Perdagangan

Yunita. 2011. "Strategi Peningkatan Kapasitas Rumahtangga Petani Padi Sawah Lebak menuju Ketahanan Pangan Rumahtangga, Kasus di Kabupaten Ogan llir dan Ogan 


\section{Copyright holder:}

Kamilia Nur Asyaro'Aida, M. Tassim Billah, Yul Harry Bahar (2020)

\section{First publication right :}

Journal of Social Science

\section{This article is licensed under:}

(c) (i) (O) 